УДК 556:627.8(470.325)

ИНФОРМАЦИОННО-АНАЛИТИЧЕСКИЙ ИНСТРУМЕНТАРИЙ ПРИ УПРАВЛЕНИИ РЕЖИМАМИ РАБОТЫ ГИДРОУЗЛА БЕЛГОРОДСКОГО ВОДОХРАНИЛИЩА

\author{
${ }^{1}$ Коржов И.В., ${ }^{1,2}$ Журавлёв А.А.
}

${ }^{1}$ ФГБУ «Российский информационно-аналитический и научно-исследовательский водохозяйственный иентр», Ростов-на-Дону, е-mail:uch-sekrwxc.shemet@yandex.ru;

${ }^{2}$ Новочеркасский инженерно-мелиоративный институт им. А.К. Кортунова ФГБОУ ВО Донской ГАУ, Новочеркасск, е-mail:sasha201133@rambler.ru

В рассматриваемом исследовании проведена оценка эффективности информационно-аналитического инструментария для управления режимами работы Белгородского водохранилища. Необходимость в разработке инструментария вызвана сложной водохозяйственной обстановкой, сложившейся в бассейне р. Северский Донец, что подтверждено результатами анализа фактических режимов работы Белгородского водохранилища за период 2010/2011-2019/2020 гг. Основаниями для разработки инструментария послужили: ввод в постоянную эксплуатацию информационно-аналитического блока контроля состояния и режимов работь водохранилищ, анализ соответствия фактических режимов действующим Правилам использования водных ресурсов в составе Автоматизированной информационной системы государственного мониторинга водных объектов (АИС ГМВО) и разработка проекта правил использования водных ресурсов Белгородского водохранилища. В статье дается краткое описание структуры, технических возможностей, а также основных достоинств информационно-аналитического инструментария. Для оценки эффективности работы разработанного инструментария выполнено моделирование основных режимов работы Белгородского водохранилища для различных по водности лет $(50 \%, 75 \%, 95 \%$ обеспеченности). Полученные результаты свидетельствуют о том, что выполненные с помощью информационно-аналитического инструментария расчеты позволяют эффективно использовать водные ресурсы водохранилища. На основе выполненных расчётов осуществляется автоматизированная подготовка информационно-аналитических материалов, что несомненно, способствует повышению оперативности принятия решений при управлении режимами работы Белгородского водохранилища. Использование информационно-аналитического инструментария для управления режимами работы водохранилища, безусловно, является одним из основных способов оптимизации режимов работы гидроузлов комплексного назначения. Информационно-аналитический инструментарий для управления режимами работы Белгородского водохранилища на р. Северский Донец успешно внедрен на рабочих местах отдела водных ресурсов Белгородской области Донского бассейнового водного управления.

Ключевые слова: режим работы водохранилища, водохозяйственный год, годовой сток, предполоводная сработка, половодье, межень, информационно-аналитический инструментарий, водохозяйственный баланс

\title{
INFORMATION AND ANALYTICAL TOOLS FOR MANAGING THE OPERATION MODES OF THE BELGOROD RESERVOIR WATERWORKS
}

\author{
${ }^{1}$ Korzhov I.V., ${ }^{1,2}$ Zhuravlev A.A. \\ ${ }^{1} F G B U$ «Russian information-analytical and research water management center», \\ Rostov-on-Don,e-mail: uch-sekrwxc.shemet@yandex.ru; \\ ${ }^{2}$ Novocherkassk Institute of Reclamation Engineering after A.K. Kortunov, \\ FGBOU VO Donskoy GAU, Novocherkassk,e-mail:sasha201133@rambler.ru
}

In this study, the effectiveness of information and analytical tools for managing the operation modes of the Belgorod reservoir was evaluated. The need to develop tools is caused by the complex water management situation in the Seversky Donets river basin, which is confirmed by the results of the analysis of the actual operating modes of the Belgorod reservoir for the period 2010/2011-2019/2020. The basis for the development of the Toolkit was put into permanent operation of information-analytical control unit the status and operation modes of the reservoirs, analysis of the actual modes with the existing Rules of water use in the Automated information system of state monitoring of water bodies (AIS SMWB) and development of draft rules of use of water resources of the Belgorod reservoir. The article provides a brief description of the structure, technical capabilities, as well as the main advantages of information and analytical tools. To assess the effectiveness of the developed tools, the main modes of operation of the Belgorod reservoir were simulated for different water years $(50 \%, 75 \%, 95 \%$ availability). The results obtained show that calculations performed using information and analytical tools allow efficient use of water resources of the reservoir. Based on the calculations performed, automated preparation of information and analytical materials is carried out, which undoubtedly contributes to improving the efficiency of decision-making in managing the operation modes of the Belgorod reservoir. The use of information and analytical tools for managing reservoir operation modes is, of course, one of the main ways to optimize the operation modes of integrated water systems. Information and analytical tools for managing the modes of operation of the Belgorod reservoir on the Seversky Donets river have been successfully implemented at the workplaces of the water resources Department of the Belgorod region of the don basin water management.

Keywords: reservoir operation mode, water management year, annual runoff, pre-water discharge, high water, mezhen, information and analytical tools, water management balance

В условиях неравномерного распределения водных ресурсов по территории Российской Федерации, наличия районов страны с их дефицитом или избытком, а также роста водопотребления для нужд населения и экономики страны в целом требуется рациональный и комплексный подход по их использованию и управлению. Одним 
из возможных решений данного вопроса является оптимизация режимов работы гидроузлов комплексного назначения, поэтому разработку информационно-аналитического инструментария для управления режимами работы водохранилища можно считать одним из способов ее достижения [1, с. 11].

Цель исследования: проведение оценки эффективности информационно-аналитического инструментария для управления режимами работы Белгородского водохранилища как одного из мероприятий оптимизации режимов работы гидроузлов комплексного назначения.

\section{Материалы и методы исследования}

Информационной базой послужили сведения о фактических режимах работы Белгородского водохранилища, данные о современном уровне водопотребления на водохозяйственном участке 05.01.04.001.01 - p. Северский Донец от истока до створа Белгородского гидроузла, а также инструментарий разработанного комплекса.

В качестве основных методов исследования были использованы эмпирический (изучение и анализ имеющихся сведений) и теоретический (моделирование) методы исследования.

\section{Результаты исследования и их обсуждение}

Белгородское водохранилище осуществляет сезонное регулирование стока р. Северский Донец для целей водоснабжения Белгородского промышленного района и частично г. Шебекино, улучшения санитарного состояния р. Северский Донец, орошения сельхозугодий, прилегающих к водохранилищу, любительского и спортивного рыболовства, отдыха жителей г. Белгорода и прилегающих районов, а также для обеспечения гарантированных расходов воды в пограничном с Украиной створе.

Основным источником питания рек в бассейне р. Северский Донец являются талые снеговые воды, поэтому его водный режим характеризуется выраженным весенним половодьем и низкой меженью в остальное время года. Весенний подъем уровней в р. Северский Донец начинается в конце февраля - начале марта. Пик половодья наблюдается в большинстве случаев в марте. Половодье продолжается 1,5-2 месяца, а в годы с затяжной весной длительность половодья увеличивается до 2,5-3 месяцев.
Последующий летне-осенний период характеризуется длительным стоянием низких уровней воды, иногда нарушаемых кратковременными дождевыми паводками.

Зимняя межень устанавливается в конце ноября и заканчивается в конце февраля - начале марта; ее продолжительность составляет 70-120 дней. Зимний период отличается устойчивостью уровней, которые по своей величине несколько выше уровней летней межени [2-4]. Основные характеристики Белгородского водохранилища приведены в табл. 1 [5].

Для оценки современного состояния Белгородского водохранилища был выполнен анализ фактического режима работы водохранилища за период 2010/2011-2019/2020 гг. (здесь и далее по тексту указываются водохозяйственные годы (в/х)). Фактические значения годового стока р. Северский Донец в створе Белгородского гидроузла за период 2010/2011-2019/2020 гг. приведены в табл. 2.

Согласно данным, полученным из электронного журнала состояния и режимов работы Белгородского водохранилища, содержащего сведения о фактических режимах работы водохранилищ, выявлено, что за рассматриваемый период:

1) максимальное наполнение Белгородского водохранилища наблюдалось 13.04.2017 - 17.04.2017, 19.04.2017, 13.04.2019 - 26.04.2019 до отметки 114,5 м в балтийской системе высот (БС), минимальное - 111 мБС (31.10.2018 - 06.11.2018). Наполнение выше НПУ 114,5 мБС не осуществлялось. Снижение отметок уровней воды в водохранилище ниже УМО 110 мБС не осуществлялось;

2) приток к водохранилищу за выбранный период составил 1225,1 млн м³. Максимальное значение суточного притока к водохранилищу расходом $38,2 \mathrm{~m}^{3} / \mathrm{c}$ наблюдалось 12.04.2018, минимальное значение 0,2 $\mathrm{m}^{3} / \mathrm{c}$ наблюдалось 29.07.2010, 20.08.2010, 23.08.2010 - 25.08.2010, 08.11.2010-09.11.2010, $11.06 .2015,09.07 .2015,14.07 .2015,09.08 .2015-$ 10.08.2015, 21.08.2015, 27.08.2015;

3) попуск в нижний бьеф водохранилища за выбранный период составил 1120,38 млн м;

4) максимальный сбросной расход $23,35 \mathrm{~m}^{3} / \mathrm{c} 25.04 .2018-27.04 .2018$, минимальный - 0,9 м м $^{3}$ с 03.10.2012, 07.06.2017 08.08.2017;

5) объемы водохранилища изменялись

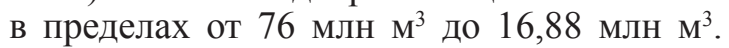
Процент наполнения изменялся в пределах от $100 \%$ до $13,21 \%$ [6]. 
Таблица 1

Основные технико-эксплуатационные характеристики Белгородского водохранилища

\begin{tabular}{|c|c|c|c|}
\hline № ח/ח & Наименование параметров & Единицы измерения & Значения \\
\hline \multicolumn{4}{|c|}{ Естественные водные ресурсы в створе гидроузла } \\
\hline 1 & Средний годовой сток & мЛН $\mathrm{M}^{3}$ & 234,9 \\
\hline 2 & Сток $0.1 \%$ обеспеченности & МлН м ${ }^{3}$ & 577,11 \\
\hline 3 & Сток 1\% обеспеченности & МлН $\mathrm{M}^{3}$ & 475,88 \\
\hline 4 & Сток 5\% обеспеченности & МлН $\mathrm{M}^{3}$ & 392,94 \\
\hline 5 & Сток $25 \%$ обеспеченности & МлН М ${ }^{3}$ & 288,87 \\
\hline 6 & Сток $50 \%$ обеспеченности & МлН $\mathrm{M}^{3}$ & 226,11 \\
\hline 7 & Сток $75 \%$ обеспеченности & МлН $\mathrm{M}^{3}$ & 170,93 \\
\hline 8 & Сток 95\% обеспеченности & млн $\mathrm{M}^{3}$ & 106,91 \\
\hline \multicolumn{4}{|c|}{ Характерные проектные уровни воды водохранилища (у плотины) } \\
\hline 1 & Форсированный подпорный уровень (ФПУ) & $\mathrm{M}$ & 114,5 \\
\hline 2 & Нормальный подпорный уровень (НПУ) & M & 114,5 \\
\hline 3 & Уровень мертвого объема (УМО) & M & 110 \\
\hline 4 & Уровень предполоводной сработки (УПС) & M & 113,5 \\
\hline \multicolumn{4}{|c|}{ Топографическая характеристика водохранилища } \\
\hline 1 & Объем водохранилища при ФПУ & млН $\mathrm{M}^{3}$ & 76 \\
\hline 2 & Объем водохранилища при НПУ & МлН м ${ }^{3}$ & 76 \\
\hline 3 & Объем водохранилища при УМО & МлН $\mathrm{M}^{3}$ & 7,88 \\
\hline 4 & Полезный объем & млн м ${ }^{3}$ & 68,12 \\
\hline 5 & Площадь зеркала при ФПУ & $\mathrm{KM}^{2}$ & 23,1 \\
\hline 6 & Площадь зеркала при НПУ & $\mathrm{KM}^{2}$ & 23,1 \\
\hline 7 & Площадь зеркала при УМО & $\mathrm{KM}^{2}$ & 7,6 \\
\hline
\end{tabular}

Таблища 2

Фактический годовой сток р. Северский Донец к Белгородскому водохранилищу за период 2010/2011-2019/2020 гг.

\begin{tabular}{|c|c|c|c|c|c|c|c|c|c|c|}
\hline В/х год & $2010 /$ & $2011 /$ & $2012 /$ & $2013 /$ & $2014 /$ & $2015 /$ & $2016 /$ & $2017 /$ & $2018 /$ & $2019 /$ \\
& 2011 & 2012 & 2013 & 2014 & 2015 & 2016 & 2017 & 2018 & 2019 & 2020 \\
\hline $\begin{array}{c}\text { Объем } \\
\text { млн м } \mathbf{~ M}^{3}\end{array}$ & 101,7 & 88,8 & 86,9 & 111,9 & 85,9 & 86,7 & 165,8 & 138,6 & 219,4 & 139,4 \\
\hline
\end{tabular}

Анализ водохозяйственной ситуации в бассейне р. Северский Донец показал, что за период 2010/2011-2019/2020 гг. лишь в 2018-2019 в/х году фактический годовой сток к Белгородскому водохранилищу практически достиг объема стока среднего по водности года $50 \%$ обеспеченности. В 2016/2017 в/х году фактический объем стока находился на уровне стока для года $75 \%$ обеспеченности, тогда как в период 2010/2011-2015/2016 гг. наблюдалась череда маловодных лет, а в 2017/182019/2020 в/х годах объем стока находился на границе объема стока для лет $75 \%$ и $95 \%$ обеспеченности (рис. 1).

Кроме того, анализ данных на продленном хронологическом графике годового стока р. Северский Донец к Белгородскому водохранилищу свидетельствует о наличии тенденции уменьшения объема годового стока (рис. 2) [3, 7]. Для продления гидрологического ряда на период 2010/2011-2019/2020 гг. были использованы данные о фактических годовых объемах стока р. Северский Донец к Белгородскому водохранилищу [6].

Ввиду сложной водохозяйственной обстановки в бассейне р. Северский Донец, разработки и ввода в постоянную эксплуатацию информационно-аналитического блока контроля состояния и режимов работы водохранилищ, анализа соответствия фактических режимов действующим Правилам использования водных ресурсов в составе Автоматизированной информационной системы государственного мониторинга водных объектов (АИС ГМВО), а также с учетом разработки проекта правил использования водных ресурсов Белгородского водохранилища 
возникла необходимость в создании информационно-аналитического инструментария для управления Белгородским водохранилищем [3, 8, 9].

Информационно-аналитический инструментарий для управления режимами работы Белгородского водохранилища на р. Северский Донец предназначен для достижения максимальной эффективности использования водных ресурсов и работы гидроузла Белгородского водохранилища. Инструментарий обеспечивает возможность оперативного расчета и корректировки вариантов режимов работы водохранилища с учетом поступающих прогнозов приточности к створу гидроузла при пропуске половодий в период летне-осенней межени и в предполоводный период [10].

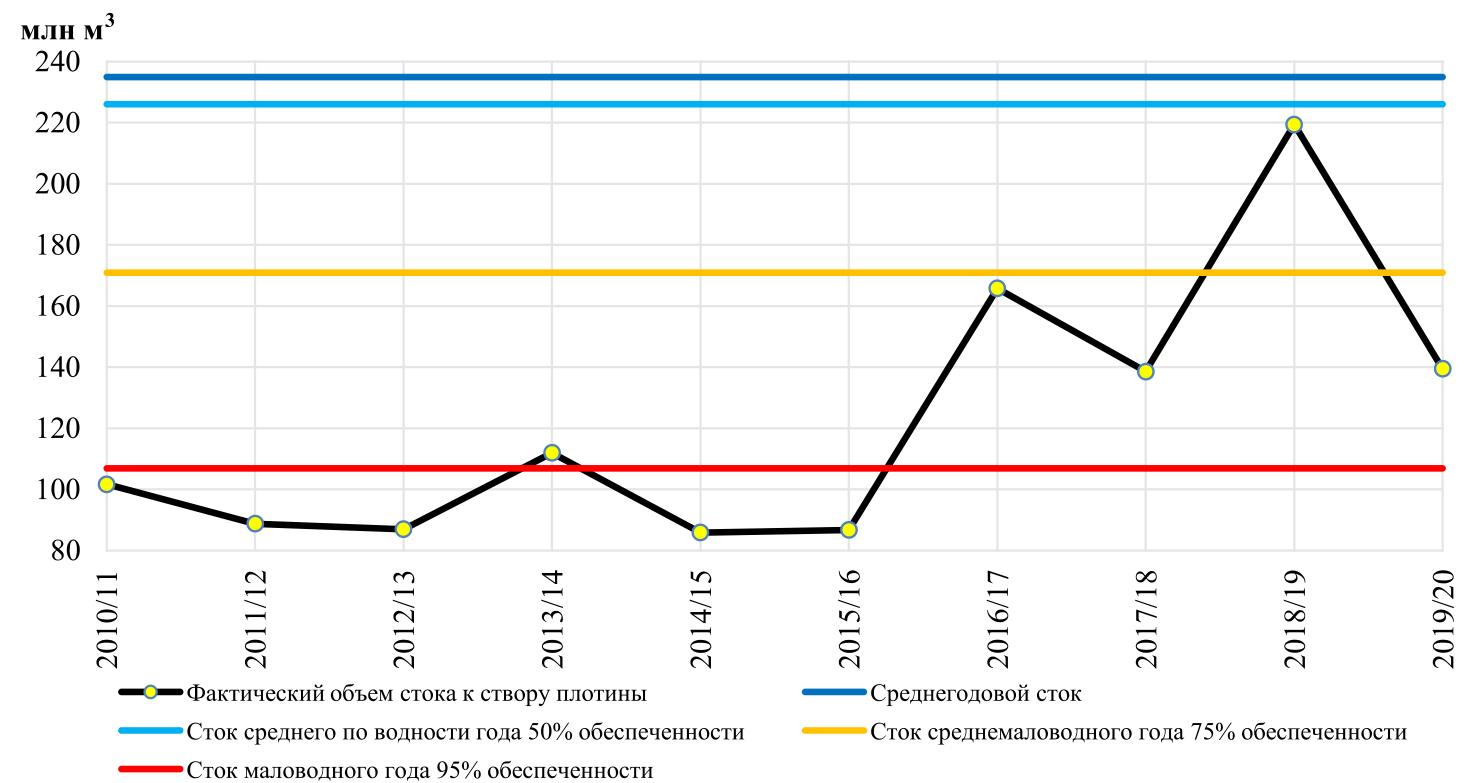

Рис. 1. Фактический годовой объем стока к Белгородскому водохранилищу за период 2010/11-2019/20 г2. относительно объема стока различной обеспеченности

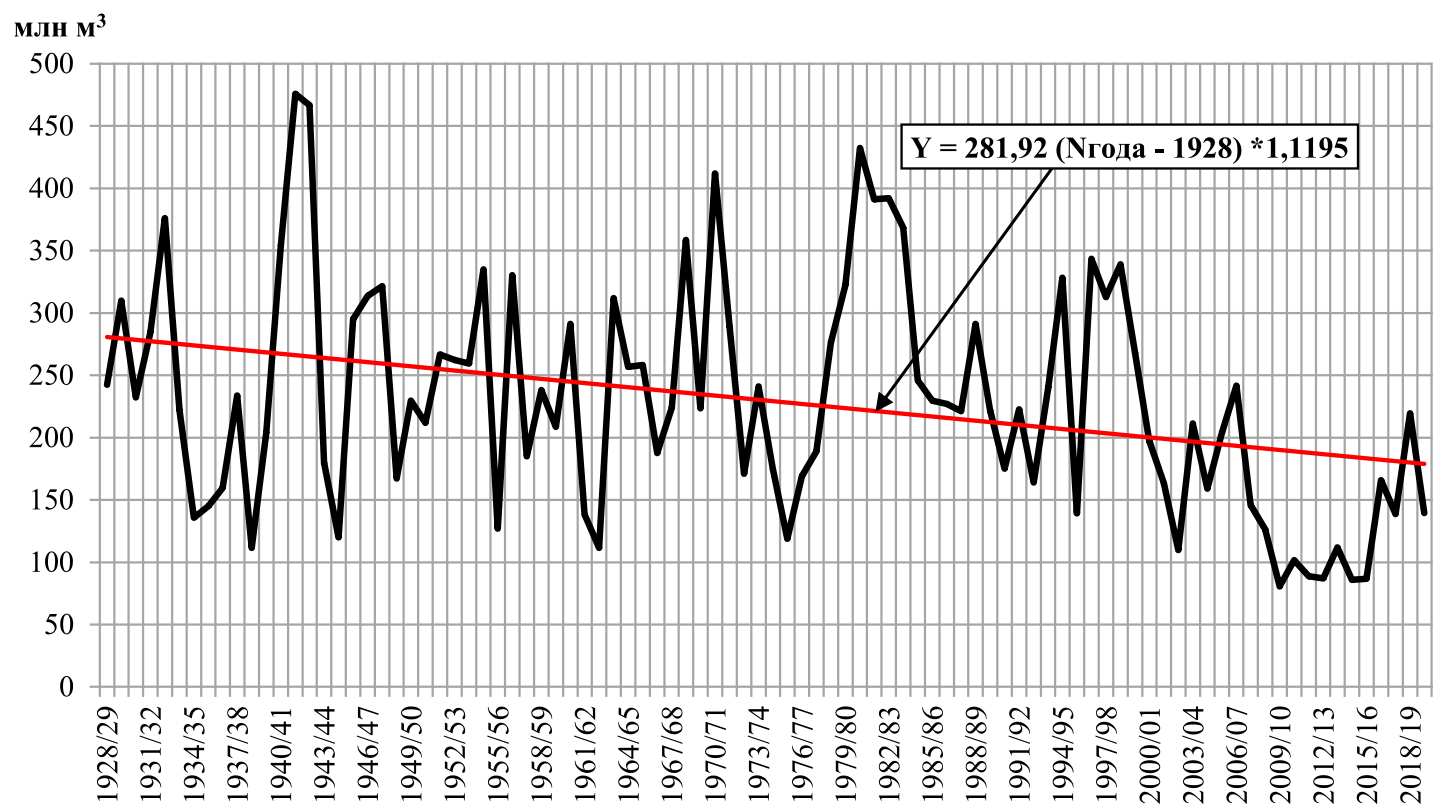

Рис. 2. Хронологический график годового объема стока р. Северский донеи к Белгородскому водохранилищу 
Структура информационно-аналитического инструментария для управления режимами работы Белгородского водохранилища представлена на рис. 3 .

В настоящее время информация о прогнозах приточности воды к створу Белгородского гидроузла на период половодья отсутствует. В соответствии с этим в комплексе предусмотрена возможность поиска, обработки и корректировки подходящего гидрографа приточности воды к водохранилищу за ретроспективный период по заданным характеристикам половодья, таким как объем половодья, максимальный расход, даты начала и конца половодья и дата прохождения пика половодья.

Также стоит отметить, что информационно-аналитический инструментарий Белгородского водохранилища успешно интегрирован с программным информационно-аналитическим комплексом анализа режимов работы водохранилищ (ПИАК), что позволяет использовать актуальную ин- формацию о фактическом режиме работы Белгородского водохранилища (сведения о приточности воды к водохранилищу, сбросу в нижний бьеф и уровне верхнего бьефа).

В качестве примера работы информационно-аналитического инструментария было проведено моделирование основных режимов работы Белгородского водохранилища: предполоводной сработки, пропуска весеннего половодья, а также работы водохранилища в период межени для разных по водности лет $(50 \%, 75 \%, 95 \%$ обеспеченности) (рис. 4). Результаты смоделированных расчетов представляются в графической и табличной форме. Табличная форма представления результатов выполнена в виде расчета водохозяйственного баланса (ВХБ) (табл. 4-6). Данные условно-естественного стока р. Северский Донец в створе Белгородского гидроузла для водохозяйственных лет $(50 \%, 75 \%, 95 \%$ обеспеченности), использованные для расчета, приведены в табл. 3 [3].

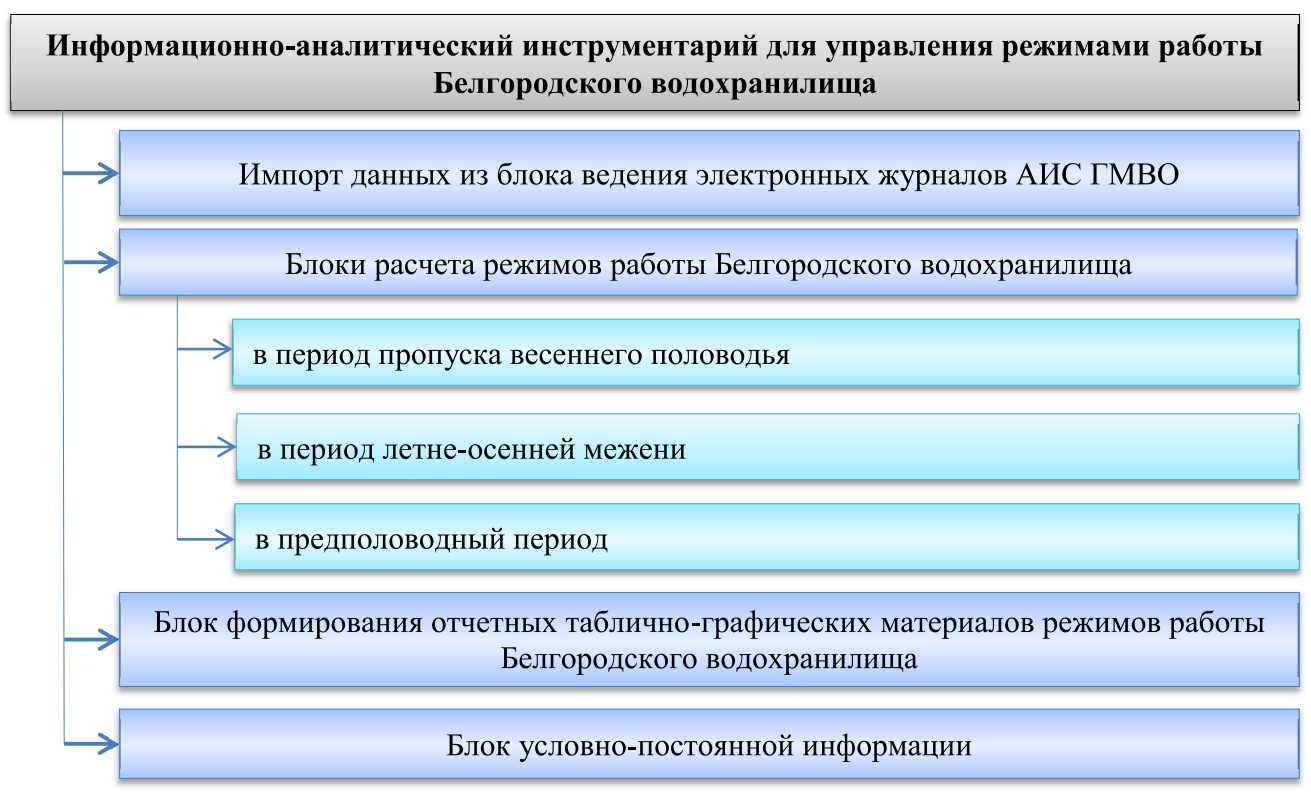

Рис. 3. Структура информационно-аналитического инструментария для управления режимами работы Белгородского водохранилища

Таблица 3

Условно-естественный сток р. Северский Донец в створе Белгородского гидроузла для водохозяйственных лет $(50 \%, 75 \%, 95 \%$ обеспеченности)

\begin{tabular}{|c|c|c|c|c|c|c|c|c|c|c|c|c|c|}
\hline \multirow{2}{*}{ В/х год } & \multicolumn{12}{|c|}{ Месяцы } & \multirow{2}{*}{$\begin{array}{l}\text { Объем, } \\
\text { млн м }\end{array}$} \\
\hline & III & IV & $\mathrm{V}$ & $\mathrm{VI}$ & VII & VIII & IX & $X$ & $\mathrm{XI}$ & XII & $\mathrm{I}$ & II & \\
\hline $50 \%$ & 12,4 & 23,5 & 4,3 & 3,5 & 4,4 & 3,4 & 4,1 & 5,9 & 5,3 & 4,3 & 7,2 & 5,9 & 221,9 \\
\hline $75 \%$ & 5,5 & 15,7 & 4,7 & 1,9 & 1,4 & 2,8 & 3,3 & 2,4 & 5,2 & 3,9 & 2,8 & 16,5 & 171,9 \\
\hline $95 \%$ & 6,2 & 3,5 & 1,8 & 1,8 & 1,6 & 0,9 & 3,5 & 6,5 & 6,5 & 2,1 & 2,5 & 1,9 & 101,8 \\
\hline
\end{tabular}


В качестве основных условий для моделируемых режимов работы водохранилища были выбраны следующие:

- уровень на начало предполоводной сработки (1 ноября) установлен 113,56 мБС;

- уровень воды в водохранилище на момент окончания предполоводной сработки (28 февраля) должен быть установлен на отметке не выше 113,5 мБС;

- использованы данные современного уровня водопотребления на водохозяйственном участке 05.01.04.001.01 - p. Северский Донец от истока до створа Белгородского гидроузла.

\section{Заключение}

Полученные результаты моделирования основных режимов работы Белгородского водохранилища свидетельствуют о том, что выполненные с помощью информационноаналитического инструментария (ИАИ) расчеты позволяют эффективно использовать водные ресурсы водохранилища. На основе выполненных расчётов осуществляется автоматизированная подготовка информационноаналитических материалов, что несомненно, способствует повышению оперативности принятия решений при управлении режимами работы Белгородского водохранилища.

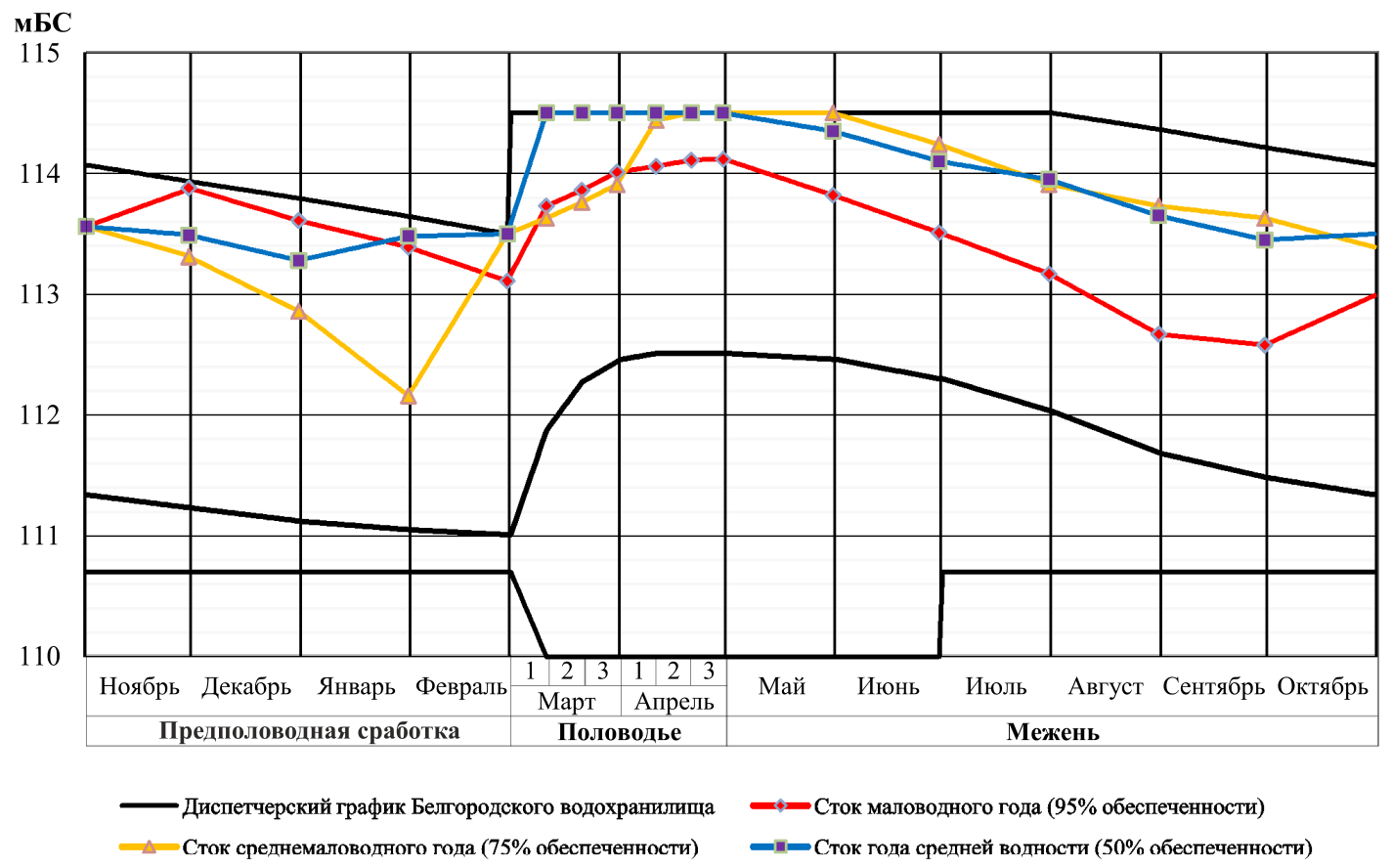

Рис. 4. Совмещенный график моделирования основных режимов работь Белгородского водохранилища в условиях различной водности

Таблица 4

Пример расчета приходной части ВХБ для года $95 \%$ обеспеченности при пропуске половодья

\begin{tabular}{|c|c|c|c|c|c|c|c|}
\hline \multirow[t]{2}{*}{ Наименование составляющей } & \multirow{2}{*}{$\begin{array}{l}\text { Итого } \\
\text { мЛн м }{ }^{3}\end{array}$} & \multicolumn{3}{|c|}{ Март } & \multicolumn{3}{|c|}{ Апрель } \\
\hline & & 1 & 2 & 3 & 1 & 2 & 3 \\
\hline \multicolumn{8}{|c|}{ Приходная часть: } \\
\hline 1. Сток на участке & 25,799 & 7,6 & 5,6 & 5,6 & 3,9 & 3,7 & 2,9 \\
\hline 2. Подзем воды, не связанный с поверхностным стоком & 6,282 & 1,192 & 1,192 & 1,192 & 1,192 & 1,192 & 1,192 \\
\hline 3. Сработка прудов и водохранилищ & 0,532 & 0,101 & 0,101 & 0,101 & 0,101 & 0,101 & 0,101 \\
\hline 4. Возвратные воды на участке & 7,51 & 1,425 & 1,425 & 1,425 & 1,425 & 1,425 & 1,425 \\
\hline 4.1. Коммунально-бытовые & 6,609 & 1,254 & 1,254 & 1,254 & 1,254 & 1,254 & 1,254 \\
\hline 4.2. Промышленные & 0,29 & 0,055 & 0,055 & 0,055 & 0,055 & 0,055 & 0,055 \\
\hline 4.3. Рыбного хозяйства & 0,611 & 0,116 & 0,116 & 0,116 & 0,116 & 0,116 & 0,116 \\
\hline Итого: & 40,123 & 10,318 & 8,318 & 8,318 & 6,618 & 6,418 & 5,618 \\
\hline
\end{tabular}


Таблица 5

Пример расчета расходной части ВХБ для года $95 \%$ обеспеченности при пропуске половодья

\begin{tabular}{|c|c|c|c|c|c|c|c|}
\hline \multirow[t]{2}{*}{ Наименование составляющей } & \multirow{2}{*}{$\begin{array}{c}\text { Итого } \\
\text { млн м } \\
\end{array}$} & \multicolumn{3}{|c|}{ Март } & \multicolumn{3}{|c|}{ Апрель } \\
\hline & & 1 & 2 & 3 & 1 & 2 & 3 \\
\hline \multicolumn{8}{|c|}{ Расходная часть: } \\
\hline 1. Коммунально-бытовое водоснабжение & 7,199 & 1,366 & 1,366 & 1,366 & 1,366 & 1,366 & 1,366 \\
\hline 2. Промышленное водоснабжение & 3,257 & 0,618 & 0,618 & 0,618 & 0,618 & 0,618 & 0,618 \\
\hline 3. Орошение & 0,084 & 0,016 & 0,016 & 0,016 & 0,016 & 0,016 & 0,016 \\
\hline 4. Сельскохозяйственное водоснабжение & 0,179 & 0,034 & 0,034 & 0,034 & 0,034 & 0,034 & 0,034 \\
\hline 5. Рыбное хозяйство & 0,611 & 0,116 & 0,116 & 0,116 & 0,116 & 0,116 & 0,116 \\
\hline 6. Наполнение прудов и водохранилищ & 0,538 & 0,102 & 0,102 & 0,102 & 0,102 & 0,102 & 0,102 \\
\hline 7. Потери в прудах и водохранилищах & 0,216 & 0,041 & 0,041 & 0,041 & 0,041 & 0,041 & 0,041 \\
\hline Итого: & 12,084 & 2,293 & 2,293 & 2,293 & 2,293 & 2,293 & 2,293 \\
\hline
\end{tabular}

Таблица 6

Пример расчета попусков, потерь и режима водохранилища в ВХБ для года 95\% обеспеченности при пропуске половодья

\begin{tabular}{|c|c|c|c|c|c|c|c|}
\hline \multirow[t]{2}{*}{ Наименование составляющей } & \multirow{2}{*}{$\begin{array}{l}\text { Итого } \\
\text { млн м }\end{array}$} & \multicolumn{3}{|c|}{ Мapт } & \multicolumn{3}{|c|}{ Апрель } \\
\hline & & 1 & 2 & 3 & 1 & 2 & 3 \\
\hline \multicolumn{8}{|c|}{ Попуски: } \\
\hline 1. Санитарная проточность & 5,27 & 1 & 1 & 1 & 1 & 1 & 1 \\
\hline 2. Дополнительный гарантированный попуск & 10,541 & 2 & 2 & 2 & 2 & 2 & 2 \\
\hline 3. Холостой сброс & 0 & 0 & 0 & 0 & 0 & 0 & 0 \\
\hline Итого: & 15,811 & 3 & 3 & 3 & 3 & 3 & 3 \\
\hline \multicolumn{8}{|c|}{ Потери: } \\
\hline 1. Потери из водохранилища на доп. испарение & 0 & 0 & 0 & 0 & 0 & 0 & 0 \\
\hline Итого: & 0 & 0 & 0 & 0 & 0 & 0 & 0 \\
\hline \multicolumn{8}{|c|}{ Режим водохранилища, млн.м³: } \\
\hline Наполнение & 12,228 & 4,342 & 2,614 & 2,875 & 1,145 & 0,972 & 0,281 \\
\hline Опорожнение & 0 & 0 & 0 & 0 & 0 & 0 & 0 \\
\hline Объем воды в водохранилище & & 59,762 & 62,375 & 65,25 & 66,395 & 67,367 & 67,648 \\
\hline Отметка уровня, м & & 113,73 & 113,86 & 114,01 & 114,06 & 114,11 & 114,12 \\
\hline \% наполнения & & 78,63 & 82,07 & 85,86 & 87,36 & 88,64 & 89,01 \\
\hline Свободная емкость & & 16,238 & 13,625 & 10,75 & 9,605 & 8,633 & 8,352 \\
\hline Дефицит & 0 & 0 & 0 & 0 & 0 & 0 & 0 \\
\hline
\end{tabular}

Одним из достоинств ИАИ Белгородского водохранилища является возможность выбора варианта расчета водохозяйственного баланса для разных режимов работы водохранилища с учетом диспетчерского графика, что позволяет автоматически определять зоны и назначение соответствующих отдач для каждого интервала времени.

Следует отметить, что использование информационно-аналитического инструментария для управления режимами работы водохранилищ является одним из мероприятий, способствующих обеспечению устойчивого водопользования [11].

Информационно-аналитический инструментарий для управления режимами работы Белгородского водохранилища на p. Северский Донец успешно внедрен на рабочих местах отдела водных ресурсов Белгородской области Донского бассейнового водного управления.

\section{Список литературы / References}

1. Журавлёв А.А. Проблема нехватки водных ресурсов для социальных, экологических и экономических нужд в Российской федерации на примере Ростовской области // Научный форум. Инновационная наука: сборник статей по материалам XIII международной научно-практической конф. № 4 (13). М.: «МЦНО», 2018. С. 5-13.

Zhuravlev A.A. The Problem of lack of water resources for social, environmental and economic needs in the Russian Federation on the example of the Rostov region // Scientific forum. Innovative science: collection of articles based on the materials of the XIII international conference. scientific-practical Conf. № 4 (13). M.: «MCNO», 2018. P. 5-13 (in Russian).

2. Белгородское водохранилище на р. Северском Донец. Технический проект. Том 2. Природные условия. Книга 1. 
Климат и гидрология. № 218-2-Т1 / «Гидропроект» им. С.Я. Жука. М., 1970. 262 с.

Belgorod reservoir on the Seversky Donets river. Technical project. Volume 2. Geographical description. Book 1. Climate and hydrology. No. 218-2-T1 / «Gidroproyekt» im. S. Ya. Zhuka. M., 1970. 262 p. (in Russian).

3. Правила использования водных ресурсов Белгородского водохранилища: пояснительная записка к проекту. Новочеркасск: СевКавНИИВХ, 2012. 341 с.

Rules for using water resources of the Belgorod reservoir: explanatory note to the project. Novocherkassk: SevKavNIIVH, 2012. 341 p. (in Russian).

4. Режимы использования водных ресурсов Белгородского водохранилища на р. Сев. Донце / ГПИО «Энергопроект», «Гидропроект». М., 1990. 59 с.

Modes of use of water resources of the Belgorod reservoir on the SEV river. Donce / SPIO «Energoproekt», «Gidroproekt». M., 1990. 59 p. (in Russian).

5. Информационно-аналитические материалы о режимах работы водохранилищ, 2018 год / Федеральное агентство водных ресурсов, Федеральное государственное бюджетное учреждение «Российский информационно-аналитический и научно-исследовательский водохозяйственный центр». Новочеркасск: Лик, 2019. 490 с.

Information and analytical materials on the modes of operation of reservoirs, 2018 / Federal Agency of water resources, Federal state budgetary institution «Russian information and analytical and research water management center». Novocherkassk: Lik, 2019. 490 p. (in Russian).

6. Электронный журнал Белгородского водохранилища АИС ГМВО. [Электронный ресурс]. URL: https://gmvo. skniivh.ru (дата обращения: 20.05.2020).

Electronic journal of the Belgorod reservoir AIS GMVO. [Electronic resource]. URL: https://gmvo.skniivh.ru (date of access: 20.05.2020) (in Russian).

7. Косолапов А.Е., Коржов И.В., Чмыхов А.А. Гидролого-водохозяйственные исследования при разработке правил использования водных ресурсов Белгородского водохранилища на реке Северский Донец // Естественные и технические науки. 2017. № 8 (110). С. 38-49.

Kosolapov A.E., Korzhov I.V., Chmikhov A.A. Hydrological and water management research in the development of rules for the use of water resources of the Belgorod reservoir on the Seversky Donets river // Yestestvennyye i tekhnicheskiye nauki. 2017. № 8 (110). P. 38-49 (in Russian).

8. Приказ Росводресурсов от 31 декабря 2015 № 320 «О вводе в постоянную эксплуатацию программного информационно-аналитического комплекса анализа режимов работы водохранилищ». Росводресурсы. 2015. 4 с

Order of the Federal Agency of water resources dated December 31, 2015 No. 320 «on putting into permanent operation of the software information and analytical complex for analyzing reservoir operation modes». Rosvodresursy. 2015. 4 p. (in Russian).

9. Приказ Росводресурсов от 10 февраля 2014 года № 35 «О вводе в постоянную эксплуатацию автоматизированной информационной системы государственного мониторинга водных объектов Российской Федерации». [Электронный ресурс]. URL:http://docs.cntd.ru/ document/420279560 (дата обращения: 20.05.2020).

Order of the Federal Agency for water resources dated February 10, 2014 № 35 «On putting into permanent operation the automated information system for state monitoring of water bodies of the Russian Federation». [Electronic resource]. URL: http://docs.cntd.ru/document/420279560 (date of access: 20.05.2020) (in Russian).

10. Разработка систем поддержки принятия решений для управления режимами водохранилищ в бассейнах со сложной водохозяйственной обстановкой: отчет о НИР (промежуточ.) ФГБУ РосИНИВХЦ / рук. Косолапов А.Е.; исполн.: Коржов И.В., Ткаченко И.В., Приходько М.А., Журавлёв А.А. Ростов-на-Дону, 2017. 98 с.

Development of decision support systems for managing reservoir regimes in basins with complex water management conditions: report on research (interim) of the Federal state budgetary institution Rosinivkhts / ruk. Kosolapov A.E.; performers: Korzhov I.V., Tkachenko I.V., Prikhodko M.A., Zhuravlev A.A. Rostov-na-Donu, 2017. 98 p. (in Russian).

11. Косолапов А.Е. Цимлянское водохранилище в условиях длительного периода пониженной водности // Водные ресурсы: новые вызовы и пути решения: сборник научных трудов. Сочи, 2017. С. 31-36.

Kosolapov A.E. Tsimlyanskoe reservoir in the conditions of a long period of low water content // Vodnyye resursy: novyye vyzovy i puti resheniya: sbornik nauchnykh trudov. Sochi, 2017. P. 31-36 (in Russian). 